\title{
Clinical characteristics of patients submitted to surgery in a dental clinic of Southern Santa Catarina\#
}

\section{Características clínicas de pacientes submetidos à cirurgia em}

\author{
Paula Fernanda de Araujo* \\ Viviane Raupp Nunes de Araújo** \\ Luciane Bisognin Ceretta** \\ Soraia Netto** \\ Marlowa Marcelino Crema** \\ Priscyla Waleska Simões** \\ Fabiano Goulart Azambuja ** \\ Renan Antônio Ceretta * *
}

\begin{abstract}
This study presents the clinical characteristics and systemic disorders of patients seen at a university clinic of oral surgery. Descriptive study that evaluated 304 records of patients undergoing surgical procedures in a clinic of Oral Surgery from 2013 to 2014. Most patients were male ( $n=154 ; 50.7 \%)$, aged 8 to 78 years, and had some kind of systemic change $(n=144 ; 47.4 \%)$. The procedures were performed over the extractions $(54.3 \%, n=165)$, and removing root remainders $(\mathrm{n}=165 ; 55.6 \%)$. There were $35(11.5 \%)$ cases of clinical complications and $101(33.2 \%)$ had harmful habits with potential to interfere in the pre, trans and postoperative periods. Systemic disorders were significantly associated with age $(p<0.001)$. It can be concluded that knowledge of the systemic situation is valuable in dentistry, since many diseases can influence prescribing and method of conduct of a particular procedure.
\end{abstract}

Keywords: Epidemiology Descriptive. Surgery. Dentistry.

\section{Resumo}

Essa pesquisa apresenta as características clínicas e alterações sistêmicas dos pacientes atendidos numa clínica universitária de cirurgia oral. Estudo descritivo em que foram avaliados 304 prontuários de pacientes submetidos a procedimentos cirúrgicos numa clínica de Cirurgia Oral no período de 2013 a 2014. A maioria dos pacientes foi do sexo masculino ( $n=154 ; 50,7 \%$ ), com idade entre 8 e 78 anos, e apresentaram algum tipo de alteração sistêmica ( $n=144$; $47,4 \%)$. Os procedimentos mais executados foram as exodontias $(54,3 \% ; n=165)$, e a remoção de restos radiculares (n=165; 55,6\%). Ocorreram 35 (11,5\%) casos de intercorrências clínicas e 101 (33,2\%) possuíam hábitos nocivos com potencial para interfeir no pré, trans e pós-operatório. As alterações sistêmicas foram significativamente associadas à idade $(\mathrm{p}<0,001)$. Pode-se concluir que o conhecimento da situação sistêmica é de grande valia na área odontológica, uma vez que diversas doenças podem influenciar na indicação e no método de conduta de um determinado procedimento.

Palavras-chave: Epidemiologia Descritiva. Cirurgia. Odontologia.

DOI: $10.15343 / 0104-7809.20164004466473$

\footnotetext{
*Programa de Pós-Graduação em Saúde Coletiva - Mestrado Profissional (PPGSCol). Universidade do Extremo Sul Catarinense. Criciúma - SC, Brasil. E-mail: paulafernandadea@hotmail.com

** Programa de Pós-Graduação em Saúde Coletiva - Mestrado Profissional (PPGSCol). Universidade do Extremo Sul Catarinense. Criciúma - SC, Brasil.

\#Article originated at the Dentistry School of the Universidade do Extremo Sul Catarinense (UNESC). Criciúma, SC, Brasil.

The authors declare that there is no conflict of interest
} 


\section{INTRODUCTION}

From the earliest days of dentistry, the search for the service was curative, where radical techniques were adopted to interrupt the painful symptoms that culminated in tooth loss. However, there was a significant evolution in the materials and techniques used, as well as a new perception of health and quality of life by the patients, seeking specialized and preventive care $^{1}$.

Different and multiple determinants can influence the use of the health service in the dental area, be they cultural factors, level of education and socio-behavioral aspects. Despite the increasing improvement of new techniques, developed to prevent injuries and preserve dental structure, exodontia is still necessary in our country, presenting a procedure widely practiced in clinical practice ${ }^{2}$.

On the other hand, the importance that the individual attributes to the dental surgeon is directly associated with the physical, social and daily performance interference that tooth and mouth disorders can generate, that is, a toothache, for example, can prevent the patient from performing routine tasks, feed themselves, communicate, being a stumbling block in interpersonal relationships ${ }^{3}$. As toothache is a problem that the individual gives importance to the dental surgeon, since he is the only professional legally qualified to cure this pain.

With the progress of science in the field of health, the life expectancy of the population increased, proportionate to the chronic diseases, related to age and/or nutritional care, in the dental area. Systemic pathologies that were formerly ignored at the time of the clinical approach, such as hypertension and diabetes, are now prominent, especially at the time of diagnosis of the oral condition, and in parallel, when planning a treatment, because if not emphasized, they can cause interference and accidents during the Clinical procedure. This way, the professional must be aware of the diseases and what type of procedure and medicine to use for these individuals, in order to develop a proper and personalized clinical behavior for each situation ${ }^{4}$.
When performing complex procedures, the dentist frequently encounters emergencies ${ }^{5}$, which are usually associated with systemic impairments that apparently did not have symptoms related to oral health, making it necessary to act promptly, which may reflect the unpreparedness of the dentistry student or dental surgeon ${ }^{5}$.

Concomitant, it is essential that the dental surgeon have knowledge about the harmful habits of the patients, since vices and customs, damage the general health, can hinder the trans and post-operative period and potentially damage the cicatrization process and the repair of surgical intervention ${ }^{6}$.

Thus, the elaboration of detailed medical records and anamnesis enables the dentist to know the clinical profile of patients, as well as health history, work activities, kinship and other general conditions. This way, it actively contributes to establishing a personalized, complete and effective treatment plan, as well as enabling the professional to be prepared for different approaches, clinical protocols or complications ${ }^{7}$. In view of this, this research sought to present the clinical characteristics of patients treated at a university oral surgery clinic.

\section{METHODS}

Descriptive study, based on secondary data (dental records) of registered appointments in medical records of patients submitted to surgical procedures at an Oral Surgery Clinic in Santa Catarina from January 2013 to February 2014, totaling a sample of 304 individuals.

The information collected in the dental records evaluated were: Numerical record of age; City of origin; Whether the patient underwent biopsy (yes or no); Exodontia (yes or no); removal of root remains (yes or no); Hypertension (presence or absence); Diabetes (presence or absence); Respiratory Disease (presence or absence); Renal Disease (presence or absence); Drug allergy (presence or absence); Sexually transmitted disease (STD) (presence or absence). 
Later, each patient was classified into a risk group according to the criteria of the American Society of Anesthesiologist (ASA I, ASA II, ASA III, ASA IV, ASA V or ASA VI). This procedure provides the best patient care that will undergo surgery; and registry of clinical symptoms (presence or absence), such as hypertensive crisis (presence or absence), lipothymia (presence or absence), oroantral communication (presence or absence), alveolitis (presence or absence) and others (presence or absence).

Finally, it was characterized the presence of harmful habits that could interfere in the pre, trans and postoperative (presence or absence), and its types: smoking (presence or absence), alcoholism (presence or absence), biting objects Absence) and drug use (presence or absence).

The information collected was organized and analyzed in the IBM Statistical Package for Social Sciences (SPSS) software version 22.0. The descriptive analysis of the variables studied was performed by the absolute frequency (n) and relative (\%) of the qualitative variables, the median and the interquartile range of the age were calculated, considering a non-Gaussian distribution for this variable.

The inferential analysis were performed with a significance level $a=0.05$ and a 95\% confidence interval. The investigation of adhesion to normal age distribution was performed using the Kolmogorov-Smirnov test, which revealed a non-Gaussian distribution.

For the "risk group" analysis, the patients were classified according to the established physical status classification scale (ASA) from which each previously calibrated investigator identified systemic factors classified according to categories ASA I, II, III, IV , V and VI.

Pearson's Chi-square test was also used to quantify the association or independence between the dichotomized age by the median, and the other categorical variables; between systemic arterial hypertension and hypertensive crisis; alveolitis and harmful habits; complication and systemic alterations; and complication and harmful habits.

The study was performed after the Committee of Ethics and Research in Human Beings of the same place of the research approved, under the protocol 913.962/2014.

\section{RESULTS}

The study included the evaluation of 304 medical records, totaling a sample of 154 (50.7\%) male patients and 150 (49.3\%) female patients. The city of origin was recorded in order to obtain an overview of the patients treated in the region of Criciúma, showing that $88.2 \%(n=268)$ of the evaluated individuals live in Criciúma, $3.3 \%(\mathrm{n}=10)$ in Içara and $8.6 \%$ $(n=26)$ in the other localities of the region. Patients were aged between 8 and 78 years, with a median of 44 (Interquartile Interval (IQ) $32-53)$ years. Other demographic information is presented in table 1.

Of the total sample, $7.6 \% \quad(n=26)$ patients underwent a biopsy that was statistically associated with age $(p=0.040)$, for histopathological investigation of intraoral lesions such as Palatine Torus, Fibroma, Keratocyst, among others. Regarding the extractions, $54.3 \%(n=165)$ of the patients were submitted to the above-mentioned procedure, of one or more elements, including third molars (when extraction was necessary). In the same segment, 165 (55.6\%) removed one or more root remains in the Oral Surgery Clinic II.

In the analyzed period of care, 144 (47.4\%) patients with some type of systemic alteration, information significantly associated with age ( $p$ $<0.001)$ were attended for surgical intervention. Of these, $58.3 \%(\mathrm{n}=84)$ were hypertensive ( $p<0.001$ when related to hypertensive crisis), $30.6 \%(n=44)$ had diabetes mellitus type I or II, $25 \%(n=36)$ had respiratory disease including asthma, bronchitis, chronic obstructive pulmonary disease (COPD), and 15.3\% ( $n=22)$ reported some type of chronic or acute kidney disease.

Among the 304 medical records evaluated, 
$15.5 \%(n=47)$ of the patients had allergic reaction to some medication, including penicillin, nonsteroidal anti-inflammatory drugs (NSAIDs) or other elective medications, and none reported hypersensitivity to any local anesthetics. Still within the totality, 4.6\% (14) had STDs (mostly hepatitis), and finally, other diseases were mentioned in the anamnesis, totaling $24(7.9 \%)$ several cases among specific cardiovascular diseases, thyroid and neurological disorders.

Patients were classified according to the ASA risk groups, a statistically significant association with age as shown in table 2.

Table 1 - Demographic presentation stratified by the dichotomized age, Criciúma (SC), Brazil, 2016.

\begin{tabular}{|c|c|c|c|}
\hline \multirow{2}{*}{ Variable } & \multicolumn{3}{|c|}{ Age } \\
\hline & $\begin{array}{c}<=\text { median }(44 \text { years }) \\
n(\%) \\
n=153\end{array}$ & $\begin{array}{c}\text { >median (44 years) } \\
n(\%) \\
n=151\end{array}$ & $\mathbf{P}$ \\
\hline \multicolumn{4}{|l|}{ Gender } \\
\hline Male & $71(46.4 \%)$ & 83 (55\%) & 0.130 \\
\hline Female & $82(53.6 \%)$ & $68(45 \%)$ & \\
\hline \multicolumn{4}{|l|}{ City } \\
\hline Criciúma & $136(88.9 \%)$ & 132 (87.4\%) & \\
\hline Araranguá & $1(0.7 \%)$ & $2(1.3 \%)$ & \\
\hline Içara & $4(2.6 \%)$ & $6(4 \%)$ & \\
\hline Cocal do Sul & $2(1.3 \%)$ & $1(0.7 \%)$ & 0.480 \\
\hline Siderópolis & $6(3.9 \%)$ & $2(1.3 \%)$ & \\
\hline Urussanga & $0(0.0 \%)$ & $2(1.3 \%)$ & \\
\hline Others & $4(2.6 \%)$ & $6(4 \%)$ & \\
\hline
\end{tabular}

Source: Research data.

Among the charts evaluated, $88.5 \%(n=269)$ did not present clinical complications, however, 35 cases $(11.5 \%)$ occurred outside the normal range. Within this small group of complications, 18 were hypertensive crises, 12 alveolitis, 6 lipothymia, 3 oroantral communication and 2 cases of tissue necrosis. Our findings revealed a statistically significant association of age, with lipothymia $(p=0.005)$ and hypertensive crisis $(p=0.003)$.

In the analysis of the systemic alterations in relation to each type of complication, we observed a statistically significant association to hypertensive crisis among patients with change $(p=0.020)$. In table 3 shows other data obtained.

Of the total sample, $101(33.2 \%)$ patients responded positively when questioned about harmful habits that could interfere in the pre, trans and postoperative periods, being $66.3 \%$ ( $\mathrm{n}$ =67) smokers, $45.5 \%=46)$ alcoholics, $20.8 \%$ $(n=21)$ with habit of biting objects, and $7.9 \%$ $(n=8)$ drug users. Although the results may suggest an association between harmful habits and the occurrence of alveolitis, there was no statistically significant difference $(p=0.193)$. 
Table 2 - Classification of the Risk Group, Criciúma (SC), Brazil, 2016.

Variable

Age

$\begin{array}{cc}<=\text { median }(44 \text { years }) & >\text { median }(44 \text { years }) \\ n(\%) & n(\%) \\ n=153 & n=151\end{array}$

Total

$\mathbf{P}$

\section{Risk Group}

\begin{tabular}{lcccc}
\hline ASA I & $120(78.4 \%)$ & $61(40.4 \%)$ & $181(59.5 \%)$ & \\
ASA II & $29(19 \%)$ & $72(47.7 \%)$ & $101(33.2 \%)$ & $<0.001$ \\
ASA III & $4(2.6 \%)$ & $18(11.9 \%)$ & $22(7.2 \%)$ & \\
\hline
\end{tabular}

Source: Research data.

Table 3 - Association between presence of systemic alteration and type of complication, Criciúma (SC), Brazil, 2016.

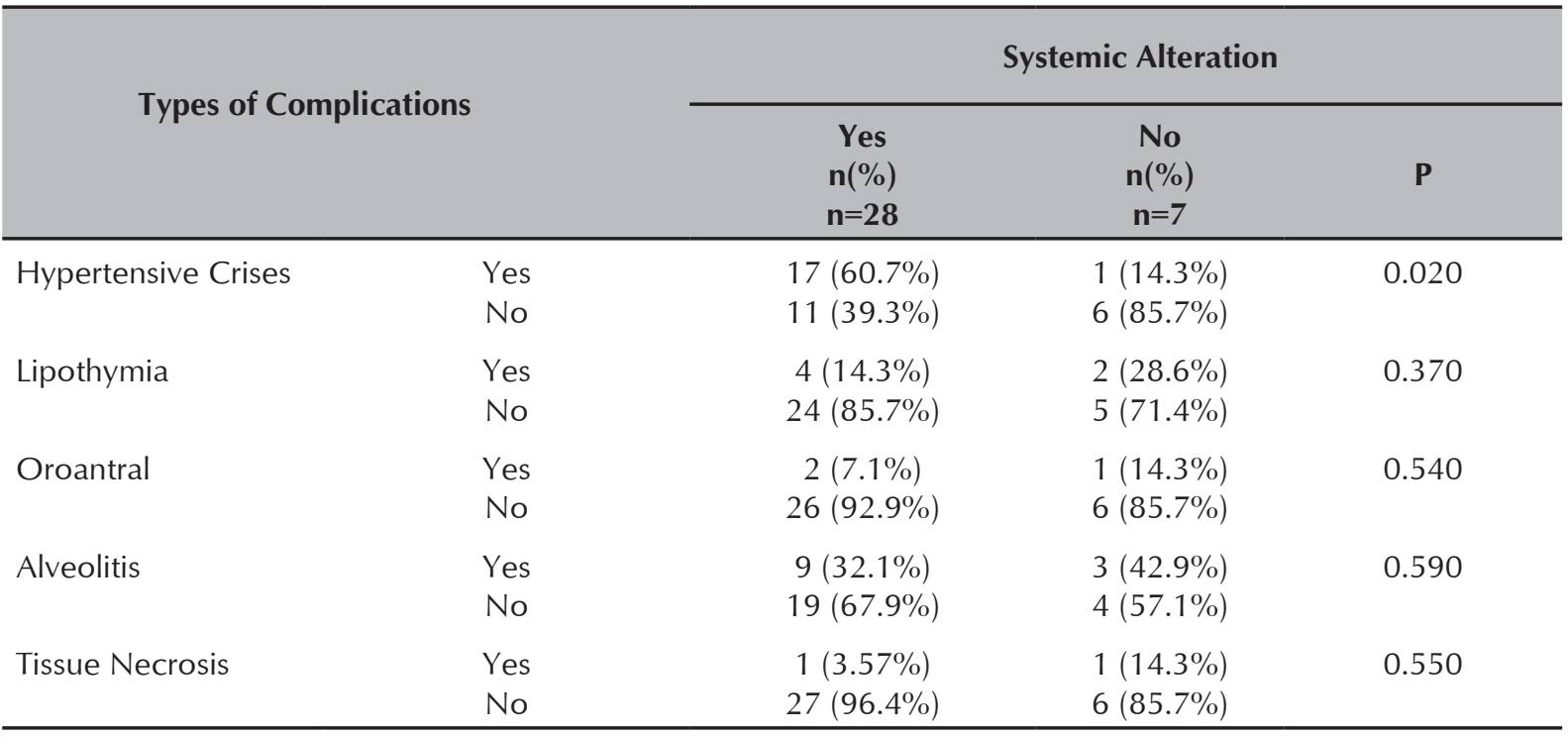

Source: Research data.

\section{DISCUSSION}

Our study aimed to present the general characteristics and most frequent systemic alterations of the patients treated at the Oral Surgery Clinic of a Southern Santa Catarina. Thus, 304 medical records of the years 2013 and 2014 were evaluated, totalizing a group of $50.7 \%$ males and $49.3 \%$ females.

It is important to reflect that the dental record is an essential tool for a procedure to be successfully, because it establishes the first interpersonal contact with the patient. The anamnesis and clinical examination reveals that it is an important moment where trust is transmitted, making the individual feel safe when performing the necessary clinical procedures ${ }^{2}$.

The anamnesis is initially composed of the 
patient's personal identification data, followed by medical and dental history, drugs of continuous use or a specific treatment, systemic pathologies, injuries, among others, which encompass not only oral health but also general health and systemic ${ }^{4,8}$.

The literature is broad regarding the importance of identifying the aggravating factors of the patient's health since the first care, since several pathologies and harmful habits can influence not only the appearance of lesions but also the postoperative condition ${ }^{1,9}$.

Some authors affirm that the anamnesis should be as complete as possible so that the treatment plan and protocol of conduct is specific to each patient's condition, so that the surgical intervention can proceed in an agreeable way and it will not compromise the clinical well-being ${ }^{8,10}$.

Knowing that the focus of oral surgery is not restricted to exodontia, but also more invasive procedures, such as biopsies, which filled $7.6 \%$ of the production of the clinic studied, the dentist should know in detail the clinical characteristics and changes of each patient, so that complications and urgent situations can be prevented $^{3}$.

Of the total sample of our study, $47.4 \%$ of the patients had some type of systemic alteration. Considering that this is a primordial information in the clinical record, a cross-sectional study sought to identify the systemic characteristics and medication use of 445 patients of the Oral Clinic at a University of São Paulo, and revealed that $23.8 \%$ of the individuals presented systemic comorbidities that could interfere with clinical management ${ }^{11}$.

Thus, Diabetes mellitus is an example of a chronic disease, caused by deficiency in the production of insulin by the pancreas. It can be hereditary or acquired, presenting in $30.6 \%$ of the individuals evaluated with some type of systemic alteration. Within the human body, insulin plays a role in regulating blood glucose, so that it remains at a normal concentration between 70 and $110 \mathrm{mg} / \mathrm{dL}^{12}$.

The discrepancy of serum glucose concentration, positive or negative, characterizes a pathological picture of hyperglycemia or hypoglycemia, respectively. Both are worrisome, since several oral pathologies may evolve from this systemic condition as a modifying factor ${ }^{13,14}$.

In this context, a review of recent literature sought to understand the predominant oral manifestations and the precautions that should be taken for the dental treatment of children with type 115 diabetes mellitus. To corroborate the data found in our study, it infers that diabetic individuals should receive careful dental care, since they are more associated with dry mouth (xerostomia), periodontitis, gingivitis, dental caries and opportunistic infections, especially when glycemia is not well-controlled ${ }^{15}$.

Among the systemic alterations, it is possible to emphasize hypertension, which was present in $27.63 \%$ of the patients submitted to the surgery clinic. This information allowed us to approach the study by Santos et $\mathrm{a}^{16}$ when it states that it is the main modifiable risk factor of clinical management since it may be associated with other heart diseases and coagulation disorders that may aggravate the risk of complications during administration of local anesthetic or surgical incisions ${ }^{16}$.

However, the same study concludes that postponing surgery due to incidentally diagnosed or inadequately controlled arterial hypertension results in discomfort to the patient and the health team, increases clinical expenses and does not decrease surgical risk ${ }^{16}$. Treating a cardiologically decompensated patient may result in reactions ranging from minor discomfort, anxiety, nausea, palpitations, dizziness, headache, tremors, tachycardia, arrhythmias, angina, and hypertension. It also can lead to a more serious condition, including cardiorespiratory arrest and death ${ }^{17-19}$.

To avoid the occurrence of systemic abnormalities and metabolic imbalances during surgery, it is essential for the professional to perform capillary glycemic check before, during and after the procedure, as well as to ensure the correct administration and prescription of trans and postoperative medications ${ }^{13}$. The importance of blood pressure measurement during all appointments, scheduling in the morning in short sessions, verification of the need for complementary sedation, can be 
emphasized so that the stress factors involved that potentially interfere in the emotional and systemic function of the patient can be reduced $^{20,21}$.

It is the responsibility of the dental surgeon to minimize infectious risk factors as well as to manipulate the buccal mucosa in an agile way in order to stimulate a process of rapid and intact healing 5 .

In the dental area, some studies suggest a close relationship between smoking and oral diseases caused by smoking ${ }^{22}$. Our sample included records of 67 smokers who may present oral health problems, such as periodontal changes, reduced blood flow, and delayed tissue healing. Therefore, if an extraction is performed under these conditions, the alveolus takes a longer time to heal, and may develop alveolitis $^{23}$, a characteristic that occurs in $17.1 \%$ of the clinical complications recorded in our series. If the sample was larger, we might find the statistical association as reported by some authors ${ }^{22}$.

It is also known that alcoholic patients (45.5\% of the individuals that had some harmful habit in our research), have medical impairments that can result in the reduction of the host's defenses ${ }^{3,4}$. In this way, the biological condition of the alcoholic allows greater admission of bacteria in the tissues or make them more active. Severe uncontrolled metabolic diseases, such as chronic alcoholism, may lead to a reduction in the leukocyte function, including chemotaxis depression, low phagocytosis, and

\section{CONCLUSION}

Based on results presented, the predominant profile of the sample was composed of male patients who presented systemic alterations significantly associated with age. The most executed procedures were the extractions and the removal of root remains. The conclusion is that the knowledge of the systemic situation is of great value in the dental area, since several diseases can influence the indication and the method of conduct of a certain procedure. Thus, the preparation to deal with different clinical low bacterial killing effectiveness ${ }^{24}$. However, although our findings suggest such association, there was no statistical significance.

The patient's resistance to understanding the importance of his contribution in interrupting the smoking habit, or alcoholism, hinders clinical behavior and consequently determines an unfavorable post operative prognosis ${ }^{6}$.

Within this context, the professional should be alert to guide his patients about the impacts that smoking and other harmful habits may have on oral and systemic health, and especially on the high risk of failure for dental treatment ${ }^{4}$.

Complications do not happen all the time, and during clinical practice, the dental surgeon may come across emergencies related to systemic diseases, not directly related to oral symptomatology. In a study conducted in the state of Paraná (Brazil), conducted by questionnaires with 142 academics from the Universidade Estadual do Oeste do Paraná (UNIOESTE), $85 \%$ of the respondents did not know about the cardiopulmonary resuscitation (CPR) in emergency rooms correctly.

To minimize the risk of clinical complications, every patient undergoing a procedure that requires anesthesia should be evaluated previously ${ }^{25}$.

The purpose of this evaluation, as recommended by the American Society of Anaesthesiologists, is to identify the patient's health status and clinical profile, to classify in pre-defined groups that help in the decision of the surgical procedure to be adopted ${ }^{5}$.

characteristics has been improved through descriptive studies that actively contribute to the determination of an epidemiological profile of a target group.

Our research shows the need to continue with the study in the professional and academic area, so that dentists in clinical experience can be prepared to deal with the profile of the patient who seeks their services, as well as changes of conduct that are necessary in surgical interventions and emergencies. 


\section{REFERENCES}

1. Travassos DB, Neves RS, Silva RG, Ribeiro ED, Tavares SSS, Paiva MAF. Perfil das exodontias realizadas na Clínica de Cirurgia I do Curso de Odontologia da Universidade Federal da Paraíba. Rev Cir Traumatol Buco-Maxilo-fac. 2009;9(1):115-22.

2. Benedicto EN, Lages LHR, Oliveira OF, Silva RHA, Paranhos LR. A importância da correta elaboração do prontuário odontológico. Odonto. 2010;18(26):41-50.

3. Sheiham A, Watt RG. The common risk factor approach: a rational basis for promoting oral health. Community Dent Oral Epidemiol. 2000;28(1):399-406.

4. Przysiezny PE, Milanezi LA, Przysiezny LTS, Cordeiro FP. Perfil da situação sistêmica do paciente pré-exodontia em postos de saúde de Curitiba. Arch Oral Res. 2011;7(2):129-40.

5. Silva EL. Avaliação do nível de conhecimento do uso de protocolos de urgência e/ou emergência médica na clínica odontológica [Dissertação]. Pará: Universidade Federal do Pará; 2006.

6. Daud SLM. A Influência do tabagismo no insucesso dos tratamentos odontológicos. [Dissertação]. São Paulo: Universidade de São Paulo; 2003.

7. Biazevic MGH, Araújo ME, Michel-Crosato E. Indicadores de qualidade de vida relacionados com a saúde bucal: revisão sistemática. Rev Odontol. 2002:13-25.

8. Pollock ML, Wilmore JH, Fox SM. Exercícios na Saúde e na Doença: Avaliação e Prescrição Para Prevenção e Reabilitação. $2^{\underline{a}}$ ed. Rio de Janeiro: Medsi; 1993. 231-605 p.

9. Pereira AMVS, Orsi JMJ, Bruzadelli RR, Trindade DL. Prevalência de patologias bucais e sistêmicas em pacientes atendidos no pronto atendimento da clínica de odontologia da UNIFENAS. J assessor Odontol. 2001;28:8-10.

10. Oliveira MMMB, Cerqueira A, Freitas VS, Freitas MA. Prevalência de indivíduos portadores de doenças de base numa clínica de extensão em cirurgia bucal: estudo preliminar. Stomatos. 2006;12(22):35-41.

11. Souza MOF, Perez ARHS, Souza TOF, Martins MAT, Bussadori SK, Fernandes KPS, et al. Incidência de alterações sistêmicas e uso de medicamentos em pacientes atendidos em clínica odontológica DOI: 10.5585/conssaude. v6i2. 1117. Conscientiae Saúde 2008;6(2):305-12.

12. Maia FR, Silva AAR, Carvalho QRM. Proposta de um protocolo para o atendimento odontológico do paciente diabético na atenção básica. Rev Espaço para a Saude. 2005:16-29.

13. Carneiro NJN, Beltrame M, Souza IFA, Andrade JM, Silva JAL, Quintela KL. Diabetic patientand their implications for dental practice. Rev Dentística. 2012;11(23):11-8.

14. Madeiro AT, ;, Bandeira FG, Figueiredo CRLV. The interrelationship between inflamatory periodontal disease and diabetes. . Odontologia Clín-científ. 2005;4(1):07-12.

15. Fernandes PM, Rocha CT, Peixoto ITA, Queiroz IF, Nelson Filho P, Queiroz AM. Abordagem odontológica em pacientes com diabetes mellitus tipo 1. Pediatria. 2010;32(4):274-80.

16. Santos TdS, Acevedo CR, Melo MCR, Dourado E. Abordagem atual sobre hipertensão arterial sistêmica no atendimento odontológico:[revisão]. Odontol clín-cient. 2009;8(2):105-9.

17. Cáceres MTF, Ludovice ACPP, Brito FS, Darrieux FC, Neves RS, Scanavacca MI, et al. Efeito de anestésicos locais com e sem vasoconstritor em pacientes com arritmias ventriculares. Arq Bras Cardiol. 2008;91(3):142-7.

18. Montan MF, Cogo K, Bergamaschi CdC, Volpato MC, Andrade EDd. Mortalidade relacionada ao uso de anestésicos locais em odontologia. RGO. 2007;55(2):197-202.

19. Oliveira AEM, Simone JL, Ribeiro RA. Pacientes hipertensos e a anestesia na Odontologia: devemos utilizar anestésicos locais associados ou não com vasoconstritores. HU Rev. 2010;36(1):69-75.

20. McGovern I. Identifying high-risk surgical patients. Pract Res Clin Anaesthesiol. 1999;13(3):243-56.

21. Silvestre FJ, Salvador-Martinez I, Bautista D, Silvestre-Rangil J. Clinical study of hemodynamic changes during extraction in controlled hypertensive patients. Med Oral Patol Oral Cir Bucal. 2011;16(3):e354-8.

22. Dinelli W, Esperança TCD, Elossais AA, Santos-Pereira NR, G; SP, S; GPPN. Analysis of gingival plaque index and oral hygiene of patients with regard to smoking. RGO. 2008;56(4):381-6.

23. Carvalho AE, Santos IDG, Cury VF. Tabagism Influence on periodontal diseases: Literature review. R Virtual Odontol. 2008:7-12.

24. Peterson LJ, Ellis E, Hupp JR, Tucker MR. Cirurgia oral e maxilofacial contemporânea. . $3^{\underline{a}}$ ed. Rio de Janeiro: Guanabara Koogan; 2000.

25. Colet D, Griza GL, Fleig CdN, Conci RA, Sinegalia AC. Acadêmicos e profissionais da odontologia estão preparados para salvar vidas? RFO 2011;16(1):25-9.

Recebido em abril de 2016. Aprovado em janeiro de 2017. 